\section{Prokudin G., Chupaylenko A., Lehid V., Khobotnia T.}

\title{
DEVELOPMENT OF METHODS TO INCREASE THE EFFICIENCY OF ROAD TRANSPORTATION BY INTERNATIONAL TRANSPORT CORRIDORS
}

The object of research is the processes of managing the functioning of international transport corridors and projects for the transportation of goods, taking into account the assessment of the quality of transport services. There is a problem of assessing the quality of the international transport process taking into account such factors as the time of delivery of goods, the speed of movement of vehicles across the customs border and the tariff, which are determined by customer requirements. All these factors depend on the logistical support of transportation projects.

The following methods were used to solve the tasks set in the work: the method of analysis of expert evaluations for the selection of project evaluation criteria; mathematical apparatus of decision theory; methods of simulation model for the assessment of the integral indicator of quality to achieve the optimal solution.

Regularities of providing conditions of continuous, safe and convenient movement of traffic flows as a basis for creation of effective system of management of processes in a network of automobile international transport corridors are defined and the methodology of definition of efficiency of their functioning is developed.

A method of forming a management system for the functioning and development of the network of international road transport corridors based on socio-economic forecasting in the form of a hierarchical structure of elements and their relationships has been developed. This made it possible to develop a model for forecasting the required amount of resources for road works on the basis of a certain demand from users of international road transport corridors.

The study is aimed at obtaining new knowledge about the regularities of improving the efficiency of road transport along the routes of European international transport corridors, which can be used as a basis for the theory of determining its positive impact on the development of the economies of countries through which international transport corridors pass. In the course of the research, the approbation of the developed technique on a choice of the optimum project of transportation at the project-oriented enterprises of motor transport is carried out.

Keywords: international transport corridors, efficiency of automobile transportations, cargo transportation project, forecasting model.

Received date: 05.03 .2020

Accepted date: 15.05 .2020

Published date: 31.08 .2020
Copyright (C) 2020, Prokudin G., Chupaylenko A., Lebid V., Khobotnia T. This is an open access article under the CC BY license (http://creativecommons.org/licenses/by/4.0)

\section{Introduction}

Transport by international transport corridors is becoming more and more stressful. For example, on Ukrainian roads the average speed is up to $30 \mathrm{~km} / \mathrm{h}$, that is, two times lower than European indicators. Tens of thousands of road traffic accidents (hereinafter referred to as RTA) occur here every year, in which thousands of people die [1]. Insufficient in length and technically backward road network of Ukraine reduces the efficiency of international transport corridors (hereinafter, ITC) on the territory of Ukraine and leads to significant losses for the economy, social problems, ecology suffers [1,2]. The development of logistics infrastructure and international road transport (especially on the ITC routes) increases competition among international carriers.

The problem is that in order to increase the efficiency of international transport, first of all, it is necessary to reduce the transport costs of enterprises. The implementation of projects for the transportation of goods along the ITC routes is a guarantee of enterprises to increase their competitiveness in the European market. The ITC development program until 2020 determines that the main task is to ensure the provision of a range of transport services that meet EU standards [3]. However, an analysis of the results of the implementation of goods transportation projects (hereinafter, GTP) shows a low level of transport and forwarding support for transportation, indicating the problems of logistics support for transportation projects. At present, the main components of effective management of road transport projects have not been developed. Consequently, there is a need to assess the quality of international transport services as a project product with factors such as delivery time, speed of movement across customs borders and tariffs that will form the project portfolio. The quality assessment of international transport services is carried out along the indicated routes. The effectiveness of solving the assigned tasks also depends on the conditions of movement along the routes of the ITC. Thus, the object of research is 
the processes of managing the functioning of international transport corridors and projects for the transportation of goods, taking into account the assessment of the quality of the provision of transport services. And the aim of research is to develop models and methods for assessing the quality of cargo transportation projects to improve the efficiency of the provision of transport services.

\section{Methods of research}

Research methods are based on the theory of complex systems. To study the problems, let's use: morphological, functional and informational descriptions of the functioning of the road network. To study complex transport systems, mathematical and simulation modeling, as well as theories of: traffic flows, road transport, management and transport and operational properties of highways are used.

As part of the general approach to conducting the study, new local approaches to the development are used:

- a comprehensive indicator for assessing transport services in the ITC network, which includes indicators of quantitative, qualitative and relay nature [4];

- methodology for choosing ITC routes, which allows increasing the competitiveness of Ukrainian carriers operating in the European and domestic markets through a reasoned choice of transportation routes [5];

- project product management model that takes into account the qualitative and quantitative characteristics of the project at each stage of the project life cycle [6].

The use of fuzzy set theory provides a multivariate choice of the most efficient route option. It is proposed to use the linguistic component of the transportation project management model, which streamlines the use of special terms [7]. It is also proposed to use a systematic approach to project management, qualimetry methods and elements of the theory of the importance of criteria.

\section{Research results and discussion}

On the example of Ukraine, new ways have been developed to increase interstate transit via the ITC routes, which can be used in international practice. For this purpose, it is proposed to use new forms of attracting international partners and build a transport infrastructure based on modern requirements [2].

It is proven that transport services must meet international standards and developed principles of quality management for international cargo transportation projects. This approach provides quality management planning and quality control of the transportation process, including the state of operation of the ITC network. Therefore, the methodology for a comprehensive assessment of the quality of transport services in the context of international road transport is proposed [8].

It is proposed to take into account the specifics of the transport service, which consists in the fact that it can't be withdrawn, corrected or altered at the stage of the implementation of the life cycle of the transportation project [9]. Therefore, a technique has been proposed that takes into account the interests of all participants in the transport process and at all stages of the project life cycle [10].

Management of transportation projects along the routes of the ITC must comply with international conventions and agreements in the field of international transportation and international standards for managing the quality of services of enterprises. The developed methods of mathematical programming for the design of transit transport networks [11, 12], taking into account the peculiarities of customs services and customs control, the peculiarities of using international transport corridors and the integrated use of various types of transport for transportation.

The result of using the developed method and computer programs is the recommendation of the optimal international route for the carriage of goods with a calculated integral estimate. The calculation results will be automatically saved in the database of the working program (Fig. 1).

The choice of a rational route for international transportation is carried out using highways of category «E», main routes of class «M» and motor routes of the UTC. At the planning phase of the project life cycle, it is proposed to use the developed fuzzy-multiple model for assessing the quality of transport services.

\begin{tabular}{|c|c|c|c|c|c|c|c|}
\hline 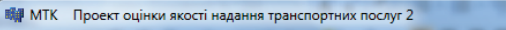 & $m+n$ & $=0$ & $2=0$ & 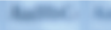 & $\pi$ & Tar & 回回 \\
\hline Критерії & route E58 & TRACEKA & MTK № 5 & route E40 & MTK № 3 & Ранг & wi \\
\hline Наявність інфрормаційного забезпечення & 0.530 & 0.530 & 0.782 & 0.913 & 0.913 & 4 & 0.139 \\
\hline Рівень сервісного обслуговування & 0.530 & 0.792 & 0.530 & 0.530 & 0.792 & 3 & 0.167 \\
\hline Рівень безпеки доставки вантажу & 0.530 & 0.792 & 0.792 & 0.975 & 0.792 & 2 & 0.194 \\
\hline Рівень якості доставки вантажу & 0.792 & 0.975 & 0.792 & 0.975 & 0.975 & 1 & 0.222 \\
\hline Рівень комплексного обслуговування & 0.975 & 0.975 & 0.975 & 0.975 & 0.975 & 5 & 0.111 \\
\hline Пропускна спроможність трансп. коридору & 0.271 & 0.365 & 0.371 & 0.365 & 0.549 & 6 & 0.083 \\
\hline Фактична інтенсивність руху автомобілів & 0.770 & 0.784 & 0.955 & 0.679 & 0.479 & 7 & 0.056 \\
\hline Кількість об'єктів, які надають серв. послуги & 0.262 & 1.000 & 0.333 & 0.262 & 0.381 & 8 & 0.028 \\
\hline Інтегральний показник якості & 0.622 & 0.786 & 0.729 & 0.805 & 0.821 & & \\
\hline \multicolumn{8}{|l|}{ Результат } \\
\hline Оптимальне рішення 0.821 & & & & & Назад & & Зберегти \\
\hline
\end{tabular}

Fig. 1. Results of calculations of the optimal international route for the carriage of goods using the computer program «5elect» 
A mathematical model has been developed that calculates an integral assessment of the quality of the provision of transport services in cargo transportation projects. The initial data for the model is the qualitative, quantitative and relay information obtained by experts. The linguistic indicator of the quality of transport services is also taken into account, it streamlines the use of the terminology for assessing the quality of international transport projects. The developed model allows to choose the optimal route according to the criterion «route attractiveness», in accordance with the requirements of customers.

The developed computer program «Select», which allows to choose the optimal international route for the carriage of goods with the calculation of 9 criteria for each route [13]. The program allows to calculate the amount of costs for the implementation of the project, assess the quality of proposals in the life cycles of the project and the efficiency of the transportation project.

\section{Conclusions}

A mathematical model has been developed that shows the relationship between the quality indicators of the implementation of transportation projects on the ITC routes and the determination of the «attractiveness» of the selected route. The model allows harmonizing the interests of all participants in the process of providing transport services, taking into account quality indicators.

Fuzzy logic methods with the application of a linguistic variable were used for the analysis of project risks. This significantly increased the efficiency of the model, since most complex management decisions are made subject to the availability of inaccurate information. The use of a linguistic variable allows to solve the problem using terminology that is different in style, content, formalization and other nature of information.

For the methodology for selecting projects for the international transportation of goods, a complex indicator was used to assess the quality of the project product. Such a complex indicator takes into account the change in financial indicators over time and indicators of the quality of transport services at various stages of the project life cycle.

The use of the developed methodology improves the quality of service for carriers and allows choosing the most efficient routes. The efficiency from the implementation of the proposed projects, taking into account a comprehensive assessment of the quality of the project product, increases by $7-15 \%$. Computer program «Select» is developed for the practical implementation of the proposed methodology for selecting ITC routes. The program uses the necessary techniques for quantitative and qualitative analysis of transportation projects, which allows to choose the optimal ITC route according to the criterion of the route's «attractiveness».

The studies performed are important and necessary for the development of a network of international transport corridors. The results of the project must be introduced in organizations and enterprises that are part of the infrastructure for the operation of international transport corridors.

\section{References}

1. Pro skhvalennia Transportnoi stratehii Ukrainy na period do 2020 roku: Rozporiadzhennia No. 2174-r. 02.10.2010 r. Kabinet Ministriv Ukrainy. Ofits. Visnyk Ukrainy, 2 (92), 545, 3280.

2. Teodorović, D., Janić, M. (2017). Transportation Systems. Transportation Engineering, 5-62. doi: http://doi.org/10.1016/b9780-12-803818-5.00002-0

3. Dunkan, W. (2004). A Guide to the Project Management Body of Knowledge. Project Management Institite Standarts Committee, 401.

4. Knight, H. (2014). New algorithm can dramatically streamline solutions to the 'max flow' problem. MIT Neres, 21-26.

5. Cancela, H., Mauttone, A., Urquhart, M. E. (2015). Mathematical programming formulations for transit network design. Transportation Research Part B: Methodological, 77, 17-37. doi: http:// doi.org/10.1016/j.trb.2015.03.006

6. Pu, C., Li, S., Yang, X., Yang, J., Wang, K. (2016). Information transport in multiplex networks. Physica A: Statistical Mechanics and Its Applications, 447, 261-269. doi: http://doi.org/ 10.1016/j.physa.2015.12.057

7. Singh, S., Dubey, C., Shrivastava, R. (2016). Various Method to Solve the Optimality for the Transportation Problem. Statistical Mechanics and its Applications, 12, 161-169.

8. Wu, J., Guo, X., Sun, H., Wang, B. (2014). Topological Effects and Performance Optimization in Transportation Continuous Network Design. Mathematical Problems in Engineering, 2, 51-68. doi: http://doi.org/10.1155/2014/490483

9. Zou, Y., Zhu, J. (2016). Reachability of higher-order logical control networks via matrix method. Applied Mathematics and Computation, 287-288, 50-59. doi: http://doi.org/10.1016/ j.amc.2016.04.013

10. Gupta, K., Arora, S. R. (2014). An algorithm for solving a capacitated indefinite quadratic transportation problem with enhanced flow. Yugoslav Journal of Operations Research, 24 (2), 217-236. doi: http://doi.org/10.2298/yjor120823043g

11. Prokudin, H. S., Kunda, N. T., Chupailenko, O. A., Lebid, V. V. (2016). Matematychna model pryiniattia optymalnoho rishennia shchodo vyboru mizhnarodnoho marshrutu za kryteriiem vazhlyvosti. Literaturnyi pysmovyi tvir naukovo-tekhnichnoho kharakteru. A. C. No. 66608. declareted: 17.05.2016 No. 66994; published: 13.07.2016, 13 .

12. Prokudin, H. S., Kunda, N. T., Chupailenko, O. A., Lebid, V. V. (2016). Nechitko-mnozhynna model zabezpechennia vzaiemozviazku pokaznykiv yakosti proektiv perevezennia vantazhiv. Literaturnyi pysmovyi tvir naukovo-tekhnichnoho kharakteru. A. C. No. 67057. declareted: 06.06.2016, No. 67469; published: 09.08.2016, 11.

13. Prokudin, H. S., Kunda, N. T., Chupailenko, O. A., Lebid, V. V. (2016). Kompiuterna prohrama «Vybir optymalnoho marshrutu rukhu za kryteriiem pryvablyvosti». A. C. No. 67055. declareted: 06.06.2016, No. 67467; published: 09.08.2016, 17.

Prokudin Georgii, Doctor of Technical Sciences, Professor, Head of Department of International Transportation and Customs Control, National Transport University, Kyiv, Ukraine, e-mail: p_g_s@ukr.net, ORCID: http://orcid.org/0000-0001-9701-8511

Chupaylenko Alexey, PhD, Associate Professor, Department of International Transportation and Customs Control, National Transport University, Kyiv, Ukraine, e-mail: dozentalexey@gmail.com, ORCID: http:// orcid.org/0000-0002-2004-0355

Lebid Viktoriia, PhD, Associate Professor, Department of International Transportation and Customs Control, National Transport University, Kyiv, Ukraine, e-mail:vikky85@ukr.net, ORCID: http:// orcid.org/0000-0002-1260-3760

Khobotnia Tetiana, Assistant, Department of International Transportation and Customs Control, National Transport University, Kyiv, Ukraine, e-mail: evol_tanya@ukr.net, ORCID: http://orcid.org/00000001-7094-6297 